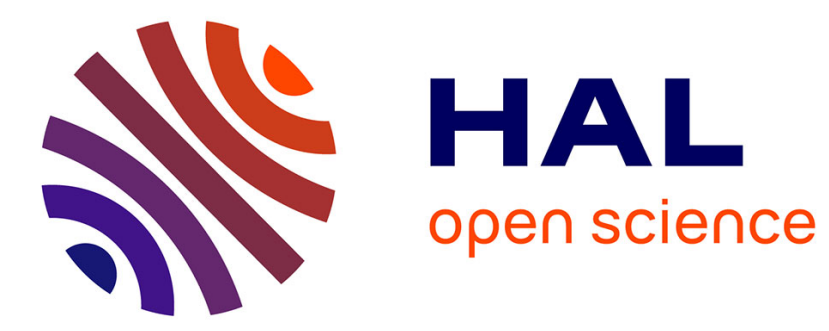

\title{
No evidence for lateral gene transfer between salmonids and schistosomes.
}

Christoph Grunau, Jérôme Boissier

\section{To cite this version:}

Christoph Grunau, Jérôme Boissier. No evidence for lateral gene transfer between salmonids and schistosomes.. Nature Genetics, 2010, 42 (11), pp.918-9. 10.1038/ng1110-918 . halsde-00608638

\section{HAL Id: halsde-00608638 \\ https://hal.science/halsde-00608638}

Submitted on 2 Feb 2012

HAL is a multi-disciplinary open access archive for the deposit and dissemination of scientific research documents, whether they are published or not. The documents may come from teaching and research institutions in France or abroad, or from public or private research centers.
L'archive ouverte pluridisciplinaire HAL, est destinée au dépôt et à la diffusion de documents scientifiques de niveau recherche, publiés ou non, émanant des établissements d'enseignement et de recherche français ou étrangers, des laboratoires publics ou privés. 
1 Correspondence

3 No evidence for lateral gene transfer from salmonids to Schistosomes (or vice

4 versa)

5 Christoph Grunau and Jérôme Boissier

6 University of Perpignan Via Domitia

7 Center for Tropical and Mediterranean Biology and Ecology

$8 \quad$ UMR5244

952 Avenue Paul Alduy

1066860 Perpignan

11 France

12 Corresponding author: christoph.grunau@univ-perp.fr

14 A study in 2004 in number 8 of this journal concluded that in the past some sort of 15 lateral gene transfer occurred from the salmonids to the schistosomes ${ }^{1}$. Schistosomes 16 are parasitic helminths that cause a severe disorder called bilharziosis or 17 schistosomiasis in humans and several animals. The deduction of gene transfer was 18 based on the analysis of an EST library for Schistosoma japonicum (Adult SjC 7/94, 19 GenBank accession number BU712912) and on PCR on genomic and cDNA of $S$. 20 mansoni and S. japonicum. The study identified salmon transposon-like sequences in 21 schistosomes, and these sequences were deposited in GenBank as schistosomes22 specific, salmon-like repeats (GenBank accession numbers AY834394 to AY834403). 23 Naturally, the report stirred up a considerable interest in the scientific community 24 since the evolutionary conclusions were far-reaching ${ }^{2-4}$. Nowadays, schistosomatidae 25 are parasitic helminths of mammals and birds, and a relation to fish that would be 26 close enough to allow for gene transfer made it necessary to reconsider the 27 evolutionary history of these blood-flukes. We show here that we find no evidence for 28 the proposed transfer of repetitive sequences from salmonids to $S$. mansoni and $S$. 29 japonicum.

30 We re-sequenced the genomes of female and male $S$. mansoni using the Genome 31 Analyzer II (Illumina) by single end sequencing according to the manufacturers 32 protocol. We obtained a total of 17,955,578 reads ( $\sim 645 \mathrm{Mb})$. Sequences are available 33 at the NCBI sequence read archive (study accession number SRA012151.6). These 
34 sequences were aligned to the 1278 repeats (total number of bp: $1,305,387$ ) in the

$\mathrm{m}$ a s k e r

d a t a b a s e

of

$S$.

mansoni

36 (ftp://ftp.tigr.org/pub/data/Eukaryotic_Projects/s_mansoni/preliminary_annotation/ho mology_evidence/sma1.repeats.gz) that includes the above-mentioned Sm_salmonid repeat (GenBank AY834402) but not the other putative salmon-like repeats. A total of $2,810,622$ reads $(15.66 \%)$ aligned to the repeats database (2-fold coverage). The Sm_salmonid sequence was the only one that did not match with any of the sequence reads. In other words, among roughly 18 million sequence bits of $36 \mathrm{bp}$, not a single read correspond to the 419 bp long previously in $S$. mansoni identified sequence of putative salmonid origin. We then used Blast searches for GenBank accession numbers AY834402, AY834401, AY834399, AY834397 and AY834395 against a local genome database of S. mansoni (S. mansoni assembly version 3.1 from ftp://ftp.sanger.ac.uk/pub/pathogens/Schistosoma/mansoni/genome/gene predictions/ GFF/S.mansoni_080508.fasta.gz ; updated march 20, 2007; 19,022 sequences; 381,096,674 base pairs; blastn default parameters; E $\leq 0.05$ ). In addition, Schistosoma whole-genome shotgun reads and the nucleotide collection at the NCBI Blast server (http://blast.ncbi.nlm.nih.gov/Blast.cgi, blastn default parameters) was searched but did not deliver significant hits ( $\geq 50 \%$ coverage, $\geq 50 \%$ identity) other than the abovementioned GenBank entries. Finally, we attempted to PCR amplify the Sm_salmonid sequences. First we used primers that were designed based on the GenBank entry AY834402 and genomic DNA extracts of $S$. mansoni larvae (cercariae) or adult worms of African and Middle American origin (Oman, Egypt, Guadeloupe and Brazil) as template. Rainbow trout (Oncorhynchus mykiss) DNA served as control for a touch-up PCR with 30 cycles starting at $42^{\circ} \mathrm{C}(18$ degrees below the calculated Tm, i.e. low stringency). In no case, amplification occurred for the schistosomes (supplementary figure $1 \mathrm{~A}$ ). We then tested the primer pairs that were originally used by Melamed et al. ${ }^{1}$ (personal communication) with genomic DNA of S. mansoni and

61 S. japonicum. In none of the reactions, amplification occurred for the schistosome samples (supplementary figure 1 B). Finally, we performed PCR with a temperature gradient between 40 and $60^{\circ} \mathrm{C}$ for the annealing temperature, 35 amplification cycles and $50 \mathrm{ng}$ S. mansoni genomic DNA. At low temperatures, amplification occurred for primer pairs Igf, PRL and LH (supplementary figure $1 \mathrm{C}$ ). The PCR products were cloned and sequenced. For LH, a PCR product of $461 \mathrm{bp}$ was amplified. This is larger than the expected size of 424 bp based on GenBank entry BU711870.1 cited in ${ }^{1}$. 
68 Alignment of the sequence of BU711870.1 spanning the primer binding sites with the sequence of the PCR product delivered $47.6 \%$ sequence identity (Needle,

70 http://www.ebi.ac.uk/Tools/emboss/align/). Comparison with the genomic sequence

71 of S.mansoni identified the PCR product as part of a unique sequence on scaffold 72000213 (position 409215-409650, 99\% identity). For the Hpa primer pairs ${ }^{1}$, the PCR 73 product has a size of $175 \mathrm{bp}$ instead of $159 \mathrm{bp}$ predicted size, and alignment with 74 AY834401.1 gives only $45 \%$ similarity. Blast finds a unique $100 \%$ match on $S$. mansoni genomic scaffold 000001 (position 1882577-1882721). For the Igf primer pair, the predicted size is $266 \mathrm{bp}$, the observed size is $1041 \mathrm{bp}$ and the similarity to AY834397.1 is very low (18.7\%). Primer sequences are given in supplementary table 1. In short, we did not observe PCR amplification with the previously used primers for the putative salmonid-like repeat sequences in S. mansoni or S. japonicum. Taken together, our experimental results, our in-silico analysis, and the schistosome and salmon eco-ethology and the literature (see supplementary note) do not support the view that gene transfer occurred from salmonids to schistosomes or between their ancestors.

84 One might wonder how such a relation could have been established in the first place.

85 The sample history of the EST library "Adult SjC 7/94" is well documented in the 86 "note" section of GenBank accession number BU712912. The authors of the database entry mention there that $2-3 \%$ of the clones contain inserts with homology to salmon DNA and apparently they considered this as contamination. Salmon sperm DNA has traditionally been used as a carrier material in many laboratories. We hypothesize that such a contamination had misguided the authors of the original article. Cross-species

91 and vector contamination would not be surprising and are found in many databases 5 .

92 We hope to initiate with the present work a re-examination of evolutionary theories 93 concerning Schistosomatidae and Salmonoidae that were based on the initial - and as we think erroneous - report of horizontal gene transfer between these clades. 
96 Author contributions

97 C.G. and J.B. designed the experiment and wrote the manuscript. C.G. performed the 98 experimental work and data analysis

99

100 Competing financial interests

101 The authors declare no competing financial interests.

102

103 References:

104

105 1. Melamed, P., Chong, K. L. \& Johansen, M. V. Nat. Genet. 36(8), 786-787 106 (2004).

107 2. de Boer, J. G., Yazawa, R., Davidson, W. S. \& Koop, B. F. BMC Genomics 8, $108 \quad 422(2007)$.

109 3. Matveev, V., Nishihara, H. \& Okada, N. Mol. Biol. Evol. 24, 1656-1666 (2007).

110 4. Matveev, V. \& Okada, N. Gene 434, 16-28 (2009).

111 5. Sorek, R. \& Safer, H. M. Nucleic Acids Res. 31, 1067-1074 (2003). 


\section{Supplementary note}

Lateral gene transfer could only be imagined if in one point of the evolutionary history, salmonid fishes were in close physical contact to schistosomes (e.g. parasited by the latter). Consequently, both groups of organisms must have lived at the same time in the same place and schistosomes must have got inside (and out) the salmonids somehow. We refer to this as encounter and compatibility filters ${ }^{1}$. From what is known about the biology of both taxonomic groups, both filters are probably closed in a hypothetical Salmonid-Schistosome host-parasite system. First, salmonids are typically cold-water fishes living higher the northern tropic, while schistosomes and their intermediate hosts occur in the intertropical zones. Moreover, both species, salmon and snail, are highly sensible to temperature variations: schistosomes do not infest under $20^{\circ} \mathrm{C}$, while upper lethal limits of salmonids is around $25^{\circ} \mathrm{C}$. For instance, in the Biomphalaria glabrata / S. mansoni host parasite system, the mortality rate of infected molluscs is $96 \%$ at $16^{\circ} \mathrm{C}$, and after 2 weeks at $15^{\circ} \mathrm{C}$ the cercarial production cease completely ${ }^{2}$. In the Oncomelania hupensis / S. japonicum host parasite system, Zhou et al. ${ }^{3}$ and Yang et al. ${ }^{4}$ described that at $21^{\circ} \mathrm{C}$ the duration of development of the parasite inside its mollusc host is two times longer compared to $30^{\circ} \mathrm{C}$. For salmonids, the negative effects of high temperatures $\left(>15^{\circ}\right)$ are also extensively documented in the literature (see ${ }^{5}$ for review). Warm temperature reduces fecundity, decrease egg survival, retard growth of fry and smolts, and increase mortality in all developmental stages. For instance, the maximum temperature for spawning and for egg or alevin to survive is only $12^{\circ} \mathrm{C}$. In other words, when schistosomes start to infect, their hypothetical salmon hosts start to die (and vice versa). Second, schistosomes parasitize only endothermic animals (birds and mammals) ${ }^{6}$. Even if schistosome cercariae could be found in the same area as a salmon species (i.e. the encounter filter would be open) it remains highly improbable for the parasite cercariae to infect the fish because host temperature is a key component of the host finding and host penetration for both $S$. mansoni and $S$. japonicum ${ }^{7-9}$. S. mansoni cercariae are attracted by a thermal gradient ${ }^{7}$ and do not attach to a cold support $\left(<25^{\circ} \mathrm{C}\right){ }^{9}$. Also $S$. japonicum cercariae migrate in the direction of high temperature and penetration starts only at $30^{\circ} \mathrm{C}$ surface temperature ${ }^{8}$. The infection of an ectothermic host is not impossible but highly improbable. One might argue that even if today a Salmonid-Schistosome host-parasite 
system is imp` ssible, gene transfer c`uld have `ccurred in an earlier system. Indeed, a sister gr` up ` $f$ the schist` $s ` m a t i d a e$, the sanguinic` lidae, are parasites ` $f$ fishes and `ne $c^{`}$ uld imagine a c`mm` $n$ ancest` $r$ that was a parasite `f ancient salm`nid fishes. The genetic distance `f schist` $s$ ' matidae $t$ ' sanguinic` lidae was estimated using the $18 \mathrm{~S}$ and 28S RNA genes, and the mit ch`ndrial cyt`chr` me c ‘xidase CO1 gene. Sequence divergence is $8 \%, 11.5 \%$ and $30 \%$, respectively ${ }^{6}$. Sequence divergence `f the putative $S$. mansoni salm`n-style repeats $\mathrm{t}^{`}$ the cl`sest salm` nid sequences is $3-5 \%$ with the excepti` $n$ 'f GenBank acc. number AY834399, a 123 bp l’ng SINE fragment (divergence 9.6\%) (supplementary table 2). These sequence divergence values $c^{\prime}$ 'resp`nd $t$ ' the genetic distance $t `$ the cl` sest salm`n species (supplementary table 2). That is $t$ ' say the genetic distance ' $f$ schist' s' matidae $t$ ' a sister gr' up is larger than the genetic distance $t$ ` the putative $d{ }^{\prime} n ` r$ species $f^{\prime} r$ the gene transfer. $C$ `nsequently, either there is str` nger selective pressure ` $n$ the repeats than ` $n$ essential genes such as rRNA, $` r$ the transfer has `ccurred after the separati` $n ` f$ the sister gr' ups. Neither the first $n ` r$ the latter (as `utlined ab`ve) is likely in `ur ` pini` $n$.

\section{Acknowledgments}

The auth `rs wish t` thank Michael Bl` uin (Oreg`n State University, C` rvallis, USA) f` $r$ the gift `f salm`n DNA, Egyptian and Oman strains `f S. mansoni were a gift `f Hélène M`né and S. japonicum adults a gift `f André Ther`n. Jean-Franç` is Allienne, Nathalie Arancibia, Bernard Dejean, and Anne R`gn`n pr`vided technical supp`rt. Rémi Emans set up the I' cal Blast databases. Illumina sequencing was d`ne at the Platef`rme MGX, Institut de Gén`mique F`ncti`nnelle, M`ntpellier. France. Discussi`n with Claude C' mbes helped t' impr`ve the manuscript tremend usly. The auth`rs are grateful t' Philippa Melamed $f^{`} r$ pr`viding inf 'rmati` $n$ ab` ut the PCR primers and c` nditi ns that were used by her.

1. C` mbes, C. Parasitism: The Ecology and Evolution of Intimate Interactions (University Of Chicag`Press, 2001).

2. Pfluger, W. Z Parasitenkd 63, 159-169 (1980).

3. Zhou, X. N. et al. Am J Trop Med Hyg 78, 188-194 (2008). 
4. Yang, G. J. et al. Parasitol. Res. 100, 695-700 (2007).

5. McCullough, D. A. Prepared for US EPA by the Columbia River Inter-Tribal Fish Commission. US Environmental Protection Agency: Washington, DC (1999).

6. Brant, S. V. et al. J. Parasitol. 92, 77-88 (2006).

7. Cohen, L. M., Neimark, H. \& Eveland, L. K. J. Parasitol. 66, 362-364 (1980).

8. Haas, W., Granzer, M. \& Garcia, E. G. J. Parasitol. 73, 568-577 (1987).

9. Haas, W., Haberl, B., Schmalfuss, G. \& Khayyal, M. T. The Journal of parasitology 80, 345-353 (1994). 


\begin{tabular}{|c|c|c|c|}
\hline Locus & $\begin{array}{l}\text { Abbreviation } \\
\text { used in the text }\end{array}$ & Forward primer & Reverse primer \\
\hline $\begin{array}{l}\text { S.mansoni } 28 \mathrm{~S} \\
\text { rDNA }\end{array}$ & $28 \mathrm{~S}$ & $\begin{array}{l}\text { 28SF1 } \\
\text { GCTGTAGTGGATCTGTGC }\end{array}$ & \multirow[t]{2}{*}{$\begin{array}{l}\text { 28SR1 } \\
\text { CTACGTCATGGGACGG }\end{array}$} \\
\hline $\begin{array}{l}\text { S. mansoni and } \\
\text { S. japonicum } \\
\text { 28S rDNA }\end{array}$ & $28 \mathrm{~S}$ & $\begin{array}{l}\text { 28SF1b } \\
\text { GGTGTAGTGGTAGACGA }\end{array}$ & \\
\hline $\begin{array}{l}\text { S.mansoni } \\
\text { specific repeat } \\
\text { W7 }\end{array}$ & W7 & $\begin{array}{l}\text { W7F } \\
\text { ATTTCACAGTTCAATCAATTGG }\end{array}$ & $\begin{array}{l}\text { W7R } \\
\text { AGATTTGCGCACAATTCC }\end{array}$ \\
\hline \multirow{2}{*}{$\begin{array}{l}\text { RSg-1-like } \\
\text { salmonid } \\
\text { retrotransposon }\end{array}$} & Rsg & $\begin{array}{l}\text { Sm_salmonid_F192 } \\
\text { GGCCATGGTGGAAAAGTAAA }\end{array}$ & $\begin{array}{l}\text { Sm_salmonid_R410 } \\
\text { AAGCACCAACTGTCAGAGCA }\end{array}$ \\
\hline & Rsg* & $\begin{array}{l}\text { RsgF } \\
\text { CTAGCTTTAAGCACCAACTGTCAG } \\
\text { AGC }\end{array}$ & $\begin{array}{l}\text { RsgR } \\
\text { GTAGGCAAGTTGAGAACAAGTTCTC }\end{array}$ \\
\hline $\begin{array}{l}\text { IGF-I } \\
\text { precursor-like } \\
\text { gene, intron } 2 \\
\end{array}$ & Igf* & $\begin{array}{l}\text { IgfF } \\
\text { GAGGGAGGTGTTTAGTCCCAGG }\end{array}$ & $\begin{array}{l}\text { IgfR } \\
\text { TAGCCATGAAGTGCTTTGAAAGGCT }\end{array}$ \\
\hline $\begin{array}{l}\text { prolactin II- } \\
\text { like flanking } \\
\text { sequence }\end{array}$ & PRL* & $\begin{array}{l}\text { PRLF } \\
\text { GCAAACCTTCTTGCCACAGCTCGC }\end{array}$ & $\begin{array}{l}\text { PRLR } \\
\text { CAGACCACTTCTCAGTTCCTATGCTTCC }\end{array}$ \\
\hline SINE SmaI & SmaI* & $\begin{array}{l}\text { SmaF } \\
\text { GACGCTTTTATCCAAAGCGACTTA } \\
\text { CAG }\end{array}$ & $\begin{array}{l}\text { SmaR } \\
\text { CTGTAGCTCAGTTGGTAGAGCATGGCG }\end{array}$ \\
\hline $\begin{array}{l}\text { LH-like } \\
\text { sequence }\end{array}$ & $\mathrm{LH}^{*}$ & $\begin{array}{l}\text { LHF } \\
\text { TGCTGGTTAAATGTGCCTTGAACTC }\end{array}$ & $\begin{array}{l}\text { LHR } \\
\text { GTGCATTAGAGTTAACTGCATCTCAG }\end{array}$ \\
\hline SINE HpaI & HpaI* & $\begin{array}{l}\text { HpaF } \\
\text { CGGCAGCGTAGCCTAGTGGTTAG }\end{array}$ & $\begin{array}{l}\text { HpaR } \\
\text { TAACCAGGCAAGTCAGTTAAGAACATA }\end{array}$ \\
\hline
\end{tabular}

Supplementary Table 1: Primers used in this work. * indicate primers used in experiments described in ${ }^{1}$ (personal communication P. Melamed) 


\begin{tabular}{|c|c|c|c|}
\hline $\begin{array}{c}\text { Putative } \\
\begin{array}{c}\text { Schistosoma } \\
\text { mansoni sequences } \\
\text { from reference 1 }\end{array}\end{array}$ & $\begin{array}{c}\text { \% difference } \\
\text { between } \\
\text { S.mansoni } \\
\text { sequence } \\
\text { sequences } \\
\text { column 1) and } \\
\text { closest } \\
\text { salmonid } \\
\text { sequence } \\
\text { (column 2) }\end{array}$ & $\begin{array}{c}\text { \% difference } \\
\text { between } \\
\text { salmonid } \\
\text { sequence } \\
\text { (column 2) and } \\
\text { closest } \\
\text { sequence of } \\
\text { another } \\
\text { salmonid } \\
\text { species }\end{array}$ \\
\hline $\begin{array}{c}\text { AY834402.1: } \\
\text { Schistosoma mansoni } \\
\text { salmonid } \\
\text { retrotransposon RSg- } \\
\text { 1-like element }\end{array}$ & $\begin{array}{c}\text { M37215.1: SMORSRSG12 } \\
\text { Oncorhynchus mykiss } \\
\text { RSg-1 repeat DNA }\end{array}$ & 5 & 4 \\
\hline $\begin{array}{c}\text { AY834401.1: } \\
\text { Schistosoma mansoni } \\
\text { SINE HpaI genomic } \\
\text { sequence }\end{array}$ & $\begin{array}{c}\text { D49900.1: ONHHOM49 } \\
\text { Oncorhynchus mykiss } \\
\text { DNA, repeat sequence }\end{array}$ & 3.5 & 4 \\
\hline $\begin{array}{c}\text { AY834399.1: } \\
\text { Schistosoma mansoni } \\
\text { SINE SmaI }\end{array}$ & $\begin{array}{c}\text { AB001880.1: } \\
\text { Oncorhynchus keta SINE } \\
\text { SmaI }\end{array}$ & 9.6 & 2 \\
\hline $\begin{array}{c}\text { AY834397.1: } \\
\text { Schistosoma mansoni } \\
\text { IGF-I precursor-like } \\
\text { gene }\end{array}$ & $\begin{array}{c}\text { EU621899.1: Salmo salar, } \\
\text { growth hormone 2 gene, }\end{array}$ & 5 & 5 \\
\hline $\begin{array}{c}\text { AY834395.1: } \\
\text { Schistosoma mansoni } \\
\text { salmonid prolactin II- } \\
\text { like flanking } \\
\text { sequence }\end{array}$ & $\begin{array}{c}\text { FJ969490.1: Salmo salar } \\
\text { MHC class I antigen }\end{array}$ & 3 & 1 \\
\hline
\end{tabular}

Supplementary Table 2: Relation of putative salmonid sequences in Schistosoma mansoni to sequences of contemporary salmonid species. 
figure I A)

\begin{tabular}{lllllllllll}
\multicolumn{3}{c}{ O. mykiss } & & \multicolumn{5}{c}{ S. mansoni } \\
& 2 & 3 & 4 & 5 & & I & 2 & 3 & 4 & 5
\end{tabular}

Rsg

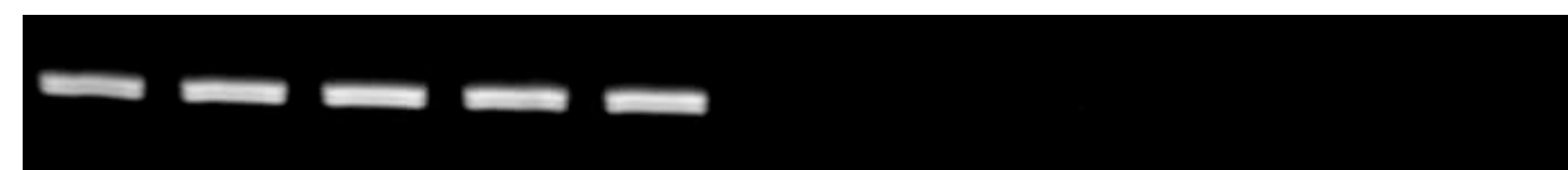

218-224 bp

$28 S$

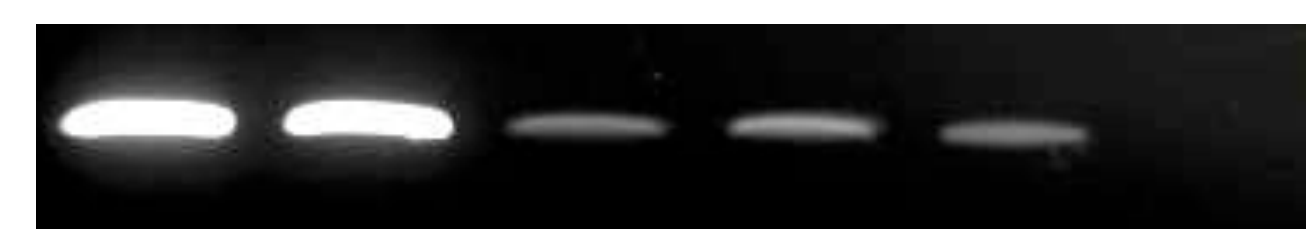

380 bp 


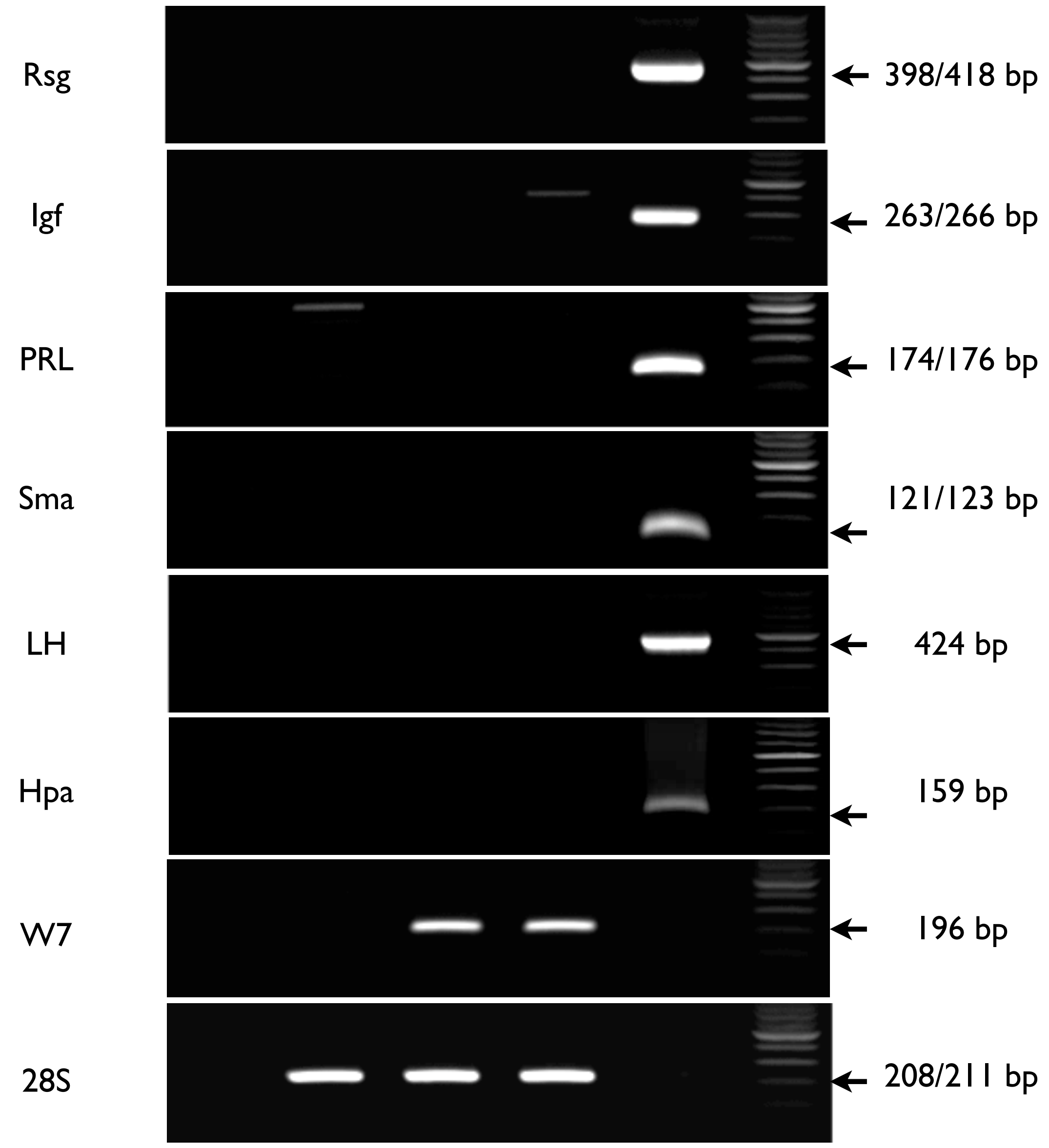



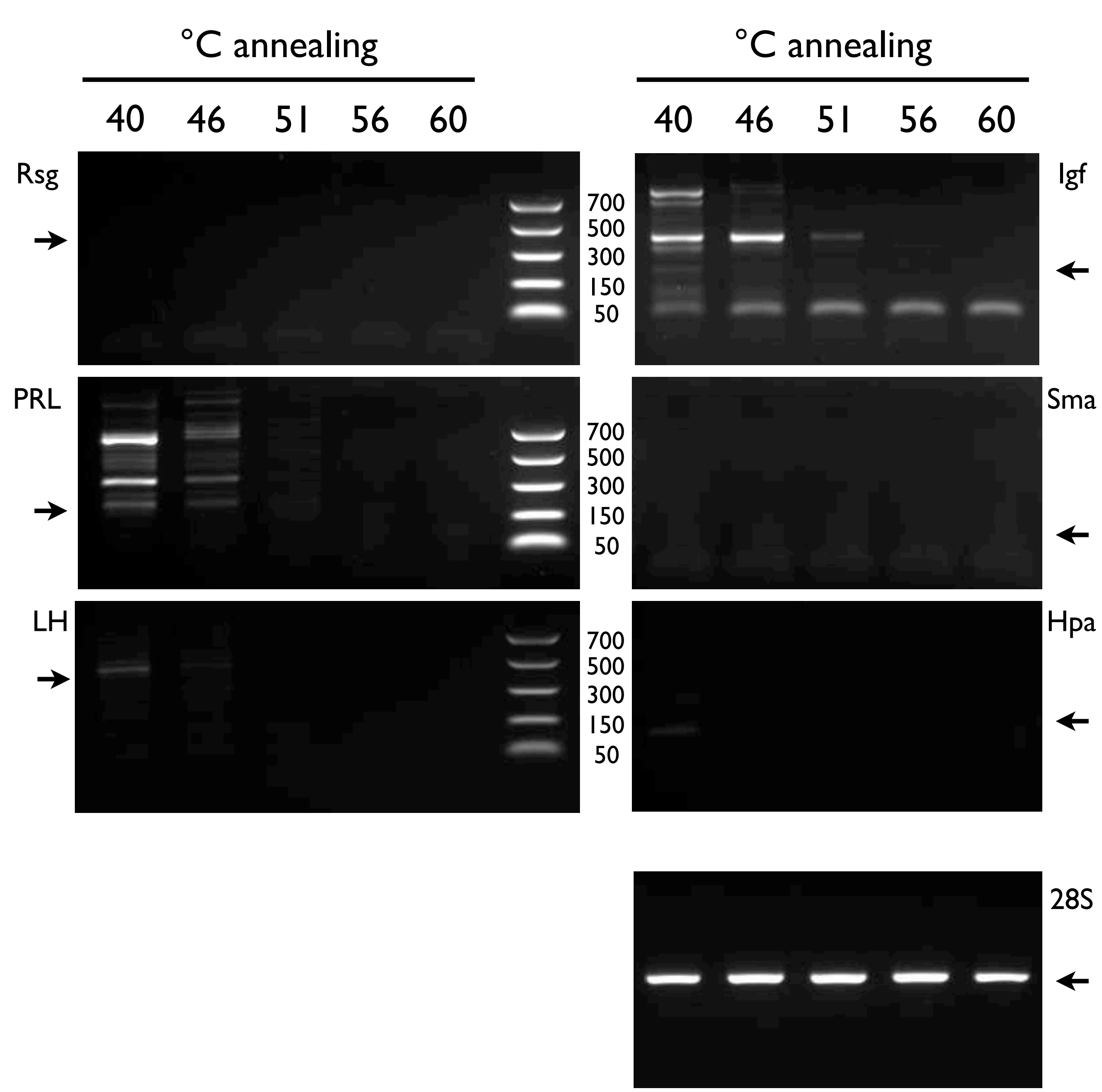


\section{Figure legend for supplementary figure 1:}

(A) Ethidiumbromide stained $1.5 \%$ agarose gels with bands corresponding to PCR products of PCR amplification of Sm_salmonid repeat Rsg and Schistosoma mansoni 28S rDNA as control for DNA presence. On the left control, reactions using Oncorhynchus mykiss genomic DNA extracts. Predicted size is 218-224 bp and corresponds to the observed one. On the right, 5 pools of $S$. mansoni genomic DNA served as templates (1: origin Guadeloupe (strain GH2), 2: origin Brazil (strain BRE), 3: origin Guadeloupe (strain DFO), 4 and 5: African origin, strains OmanM and Egypt). Negative control (c-) without template. (B) Ethidiumbromide stained 1.2\% agarose gels with products of PCR amplification of Sm_salmonid repeat Rsg, IGF, PRL, SmaI, LH, HpaI, S.mansoni specific repeat $\mathrm{W} 7$, and $S$. mansoni and $S$. japonicum specific $28 \mathrm{~S}$ rDNA (primer sequences in supplementary table 1). Fifty nanograms of template genomic DNA were used (touch down PCR annealing at $42-47^{\circ} \mathrm{C}$ for 5 cycles, constant $52^{\circ} \mathrm{C}$ for 30 cycles). (C) Ethidiumbromide stained 2\% agarose gels with products of PCR amplification on 50 ng S.mansoni genomic DNA. A gradient of amplification temperature was used and is indicated on the top. Primer pairs as in (B). Arrowheads indicate expected size. 